\title{
The effect of temperature on the interaction of Haemophilus ducreyi with human epithelial cells
}

\author{
SESUPO C. MAKAKOLE and A. WILLEM STURM \\ Department of Medical Microbiology and MRC Genital Ulcer Disease Research Unit, Faculty of Medicine, \\ University of Natal, Durban, South Africa
}

To investigate if temperature affects the interaction of Haemophilus ducreyi with human epithelial cells, nine strains were used to evaluate the adhesion kinetics of the organism at $33^{\circ} \mathrm{C}$ and $37^{\circ} \mathrm{C}$. The effect of the free toxin on the epithelial cells at those temperatures was also assessed. The cyto-adherence kinetics of $\boldsymbol{H}$. ducreyi to the epithelial cells was significantly greater at $33^{\circ} \mathrm{C}\left(10\right.$ times more) than at $37^{\circ} \mathrm{C}$ in all seven clinical isolates tested. There was a significant difference in cell-associated $H$. ducreyi at $33^{\circ} \mathrm{C}$ as compared with $37^{\circ} \mathrm{C}$. Control strains showed similar adhesion properties at both temperatures. However, the virulent strain CIP542 adhered in larger amounts than the avirulent strain A77. Electron microscopy revealed that there was more tissue necrosis at the lower than the higher temperature. The effect of the free toxin was the same at each temperature. However, strain A77 had significantly lower toxicity than strain CIP542 and the clinical isolates. These results suggest that $H$. ducreyi displays a temperature-dependent interaction with human epithelial cells, and this feature may play a role in the virulence of the organism in vivo. While the overall toxic effect of viable bacteria depends on the metabolic activity of the bacteria and is, therefore, higher at $33^{\circ} \mathrm{C}$ than at $37^{\circ} \mathrm{C}$ with the same initial inoculum, the effect of the extracted toxin at molecular level with fixed concentrations is a temperatureindependent event.

\section{Introduction}

Haemophilus ducreyi is the aetiological agent of chancroid, a sexually transmitted genital ulcer disease prevalent in developing countries $[1,2]$. Chancroid has been associated with an increased risk for the acquisition and transmission of HIV in countries with a high prevalence of HIV infection [2-4].

H. ducreyi is strictly a human pathogen that primarily infects the skin. There is limited knowledge about the mechanisms by which this organism causes disease. Successful colonisation of a host by bacterial pathogens depends on the ability of the pathogen to interact with host cells. This is a complex event involving a pathogen-encoded ligand and a eukaryotic receptor [5]. A microbe has a choice of three types of host components with which it can interact: secreted cell products, host cell surfaces or extracellular matrices [6]. Adherence of $H$. ducreyi to host cell surfaces has been widely reported [6-9]. However, these studies

Received 19 June 2000; revised version received 11 Aug. 2000; accepted 23 Aug. 2000.

Corresponding author: Professor A.W. Sturm (e-mail: sturm@med.und.ac.za). examined the interaction of the organism with these cells at temperatures of $35-37^{\circ} \mathrm{C}[4,8,10-12]$. Interaction of a pathogen with host cells may depend on environmental factors such as temperature. H. ducreyi interaction with host cells in vivo is mainly with the skin, an organ of lower temperature $\left(c .33^{\circ} \mathrm{C}\right)$. This is also the optimal incubation temperature for the $H$. ducreyi in vitro $[13,14]$. Therefore, temperature may play a role in the expression of virulence determinants of $H$. ducreyi. It was postulated that expression of attachment and virulence that affects keratinocytes may be upregulated at $33^{\circ} \mathrm{C}$, because this is both the temperature of the host at the common site of infection and the optimal growth temperature for $H$. ducreyi. To test this hypothesis, this study compared the interaction of $H$. ducreyi with epithelial cells at the optimal $H$. ducreyi growth temperature of $33^{\circ} \mathrm{C}$ and the core body temperature of $37^{\circ} \mathrm{C}$.

\section{Materials and methods}

\section{Bacterial strains and inoculum preparation}

Nine $H$. ducreyi strains were used; seven were clinical isolates from Durban, South Africa: SA26, SA42, SA60, SA63, SA68, SA71 and SA77. Reference strains 
A77 and CIP542 served as avirulent and virulent controls, respectively (A. W. Sturm, unpublished data). The strains were cultivated on Modified Bieling (MB) plates containing IsovitaleX $1 \%$ or yeast dialysate $2 \%$ [13]. The plates were incubated at $33^{\circ} \mathrm{C}$ in microaerobic conditions for $48 \mathrm{~h}$. The purity of $H$. ducreyi was confirmed by colonial morphology and Gram's stain.

For preparation of the inocula, bacteria were harvested from plates and washed three times in phosphatebuffered saline (PBS). The suspension was vortex mixed and passed 10-15 times through 25-gauge needles to further break down large clumps. The suspension was allowed to stand for $1 \mathrm{~h}$ for larger clumps to settle by gravity. The supernate was aspirated and the OD was adjusted to 1.0 at $600 \mathrm{~nm}$ (Glock and Sturm, unpublished observations). Colony forming units (cfu) were estimated by plating out serial dilutions from the adjusted supernate.

\section{Preparation of sonicates}

H. ducreyi was scraped off four plates and suspended in $10 \mathrm{ml}$ of $\operatorname{EMEM}\left(c .10^{4} \mathrm{cfu} / \mathrm{ml}\right)$, then washed three times with PBS by centrifugation at $1200 \mathrm{rpm}$ for $5 \mathrm{~min}$. The pellet was resuspended in EMEM and sonicated with a Branson sonicator at $60 \%$ duty cycle for $5 \mathrm{~min}$ with 1-min cycles. The sonicate was centrifuged to remove the debris. The supernate was filtered through a $0.22-\mu \mathrm{m}$ pore size filter. The sonicates were stored at $-20^{\circ} \mathrm{C}$ and diluted 1 in 4 with EMEM when required for experiments.

\section{Tissue-culture systems}

The HaCaT keratinocytes (provided by Professor Füsenig of the German Cancer Research Centre, Heidelburg) and HEC-1-A (ATCC HTB111) were used for attachment assay and cytotoxicity studies. HEC-1-A cells were cultivated in McCoy's 5a medium supplemented with fetal calf serum (FCS; Delta Bioproducts, Kempton Park, South Africa) 5\%, non-essential amino acids (NEAA, BioWhittaker, MD, USA) $1 \%$, penicillin $100 \mathrm{U} / \mathrm{ml}$, streptomycin (BioWhittaker) $100 \mu \mathrm{g} / \mathrm{ml}$ and amphotericin B $5 \mathrm{mg} / \mathrm{ml}$. HaCaT cells were cultivated in EMEM supplemented with FCS 5 or $10 \%$ and other supplements similar to those used for HEC-1-A cells. The cell cultures were incubated at $37^{\circ} \mathrm{C}$ in humidified air with $\mathrm{CO}_{2} 5 \%$. Each well of 24-well cluster plates (Corning Glass Works, NY, USA) was seeded with $1 \times 10^{5}$ cells and incubated for $24 \mathrm{~h}$ before use in attachment studies. Cell viability was established by the trypan blue exclusion method. The number of cells/ monolayer before infection was estimated at $3 \times 10^{5}$ (mean of three estimations) at $33^{\circ} \mathrm{C}$ and $37^{\circ} \mathrm{C}$ respectively. The cells were washed thoroughly with PBS and the medium was replaced with antibiotic-free medium before use in experiments.

\section{Adhesion assay}

This assay was performed by the method described by Lagergård et al. [15] with slight modifications. Briefly, $250 \mu \mathrm{l}$ of $H$. ducreyi suspension in EMEM-FCS were added to each well to yield a multiplicity of infection (MOI) of 10 bacteria/eukaryotic cell. The inoculated monolayers were incubated in air with $\mathrm{CO}_{2} 5 \%$ at $33^{\circ} \mathrm{C}$ and $37^{\circ} \mathrm{C}$. Tests were performed at $2,5,12,16$ and $24 \mathrm{~h}$ after inoculation. At the designated times, the infected monolayers were washed five times in PBS to remove unbound bacteria. Distilled water $(1 \mathrm{ml})$ was added and the plates were placed on a platform shaker with gentle shaking for $5-10 \mathrm{~min}$ to release both internalised and adherent bacteria (total bacterial count). Two-fold serial dilutions were made from the suspension. Portions $(20 \mu \mathrm{l})$ of the dilutions were plated out in duplicate on $\mathrm{MB}$ plates and colony counts were done after incubation for 3-4 days. Internalised bacteria were counted by the amikacin protection/invasion assay. Briefly, after removal of nonadherent bacteria by washing in PBS, $1.5 \mathrm{ml}$ of amikacin $(30 \mu \mathrm{g} / \mathrm{ml}$ in PBS) was added to each well. After $2 \mathrm{~h}$, the antibiotic was removed by washing in PBS (five times) and the cells were lysed with distilled water to release intracellular bacteria. This was followed by plating out on MB agar and the numbers of cfu were counted after incubation as described above. The adherent bacteria were assessed from the equation:

$$
\begin{aligned}
& \text { number of adherent bacteria }= \\
& \text { total number of bacteria }- \text { internalised bacteria. }
\end{aligned}
$$

Samples were fixed in glutaraldehyde 1\% in EMEMFCS for transmission electron microscopy (TEM). After removal of the fixative, the monolayers were washed and placed in EMEM-FCS and held at $4{ }^{\circ} \mathrm{C}$ before TEM processing.

\section{Cytotoxicity assay}

Epithelial monolayers were prepared by adding $10^{4}$ cells to each well of a 96-well flat-bottomed microtitration plate (Greiner Labortechnik, Frickenhausen, Germany). Portions of the sonicate $(50 \mu \mathrm{l})$ were added to each well containing $200 \mu \mathrm{l}$ of antibiotic-free medium. The monolayers were exposed to the crude toxin or viable bacteria for $60 \mathrm{~h}$, followed by aspiration of the medium and washing of the monolayers with PBS. The medium was replaced with $50 \mu \mathrm{l}$ of MTT (3(4.5-dimethylthiazol-2-yl) 2,5-diphenyl-tetrazolium bromide) (Sigma, Pinetown, South Africa) at a concentration of $5 \mathrm{mg} / \mathrm{ml}$ in EMEM-FCS and incubated for a further $4 \mathrm{~h}$ at $37^{\circ} \mathrm{C}$. This was followed by addition of $100 \mu \mathrm{l}$ of the lysin reagent, which consisted of SDS:N,N-dimethylformamide (DMF) $1: 1$. After overnight incubation at $37^{\circ} \mathrm{C}$, the $\mathrm{OD}$ was measured at $570 \mathrm{~nm}$ with an ELISA reader, employing the lysin reagent as the blank. 


\section{TEM}

Cells were grown on tissue-culture slides (Nunc, Illinois, USA). Briefly, 250-300 $\mu \mathrm{l}$ of $10^{4}$ cells $/ \mathrm{ml}$ were seeded in each well of the chamber $24-48 \mathrm{~h}$ before infection with $H$. ducreyi. Portions $(50 \mu \mathrm{l})$ of the previously prepared inoculum were added to each of the wells and incubated for the same time intervals as above. The previously fixed samples were retrieved from the refrigerator and washed again before further processing. Samples were treated with osmium tetroxide $1 \%$ at $4^{\circ} \mathrm{C}$ for $1 \mathrm{~h}$, washed four times with PBS, then dehydrated through a graded series of ethanol and embedded in Spurr resin (Sigma). Ultra-thin sections were cut and doublestained with uranyl acetate and lead citrate. Viewing was done with the JEOL 1010 transmission electron microscope with an accelerating voltage of $60-80 \mathrm{kV}$. Photographs were taken on Ilford fine grain plate film.

\section{Statistical analysis}

Student's $t$ test was applied; $\mathrm{p}$ values were considered significant if they were $<0.05$. Duncan's multiple range test [16] was applied to determine the similarities between strains.

\section{Results}

\section{Adherence studies}

The adherence of the control strains to the cells is shown in Fig. 1. Both showed similar adhesion kinetics at $33^{\circ} \mathrm{C}$ and $37^{\circ} \mathrm{C}$. Adherence was rapid, reaching a peak at $16 \mathrm{~h}$ for strain A77. Strains A77 and CIP542 showed different adhesion kinetics, with a significantly lower adherence of strain A77 at both temperatures. No peak was reached within $24 \mathrm{~h}$ at either temperature with strain CIP542. The adherence kinetics of the seven clinical isolates are summarised in Fig. 2. There

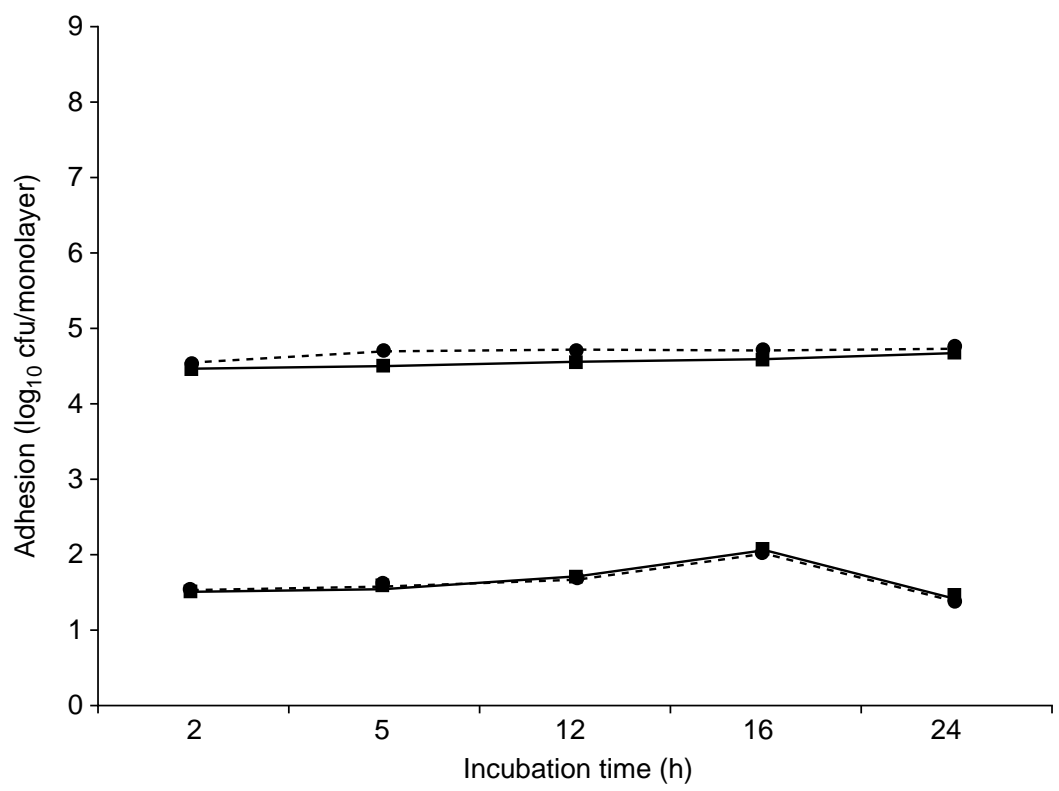

Fig. 1. Adhesion kinetics of $H$. ducreyi control strains CIP542 (top) and A77 (bottom) to epithelial cells at $33^{\circ} \mathrm{C}(---)$ and $37^{\circ} \mathrm{C}(-) ; \mathrm{p}>0.05$.

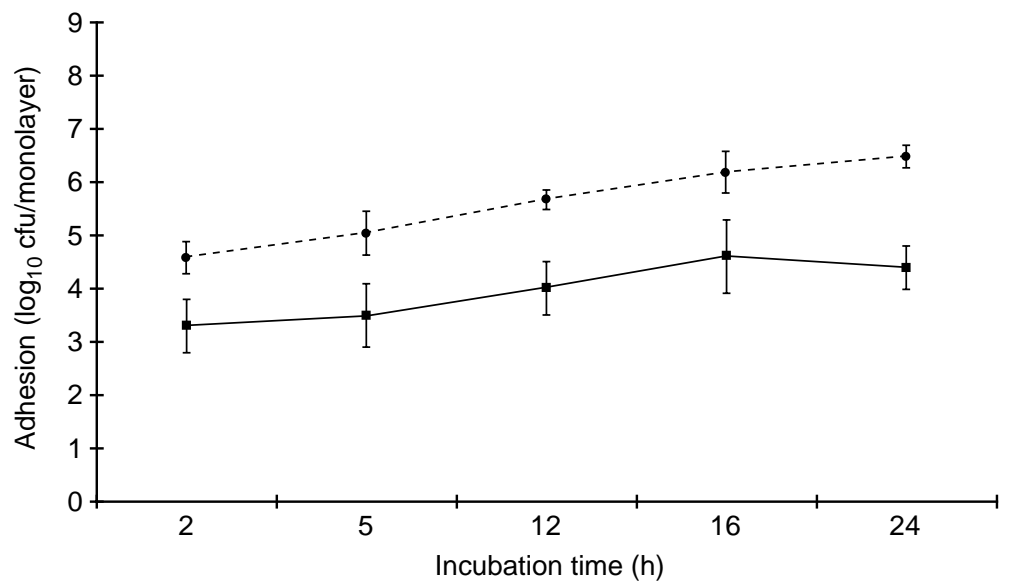

Fig. 2. Adhesion kinetics of seven clinical isolates (means) at $33^{\circ} \mathrm{C}(---)$ and $37^{\circ} \mathrm{C}(-) ; \mathrm{p}=0.0001$. 
was a significant difference between the adhesion at $33^{\circ} \mathrm{C}$ and $37^{\circ} \mathrm{C}$, with $H$. ducreyi isolates adhering 10 fold more at $33^{\circ} \mathrm{C}(\mathrm{p}=0.00016)$. At $2 \mathrm{~h}$ after infection, an average of $60 \%$ of $\mathrm{H}$. ducreyi had adhered at $33^{\circ} \mathrm{C}$ whereas c. $35 \%$ had adhered at $37^{\circ} \mathrm{C}$. The intra-strain variation at $33^{\circ} \mathrm{C}$ was $47-69 \%$ and $16-45 \%$ at $37^{\circ} \mathrm{C}$, with an SD of 0.43 . Adherence at $33^{\circ} \mathrm{C}$ continued to rise throughout for the full $24 \mathrm{~h}$ of the experiment. However, at $37^{\circ} \mathrm{C}$, a peak of adherence was reached at $16 \mathrm{~h}$. Results of individual adhesion kinetics of the clinical isolates are illustrated in Fig. 3. When the strains were classified according to the magnitude in difference of adherence to epithelial cells at the two temperatures, it was found that strain SA68 was a unique isolate with the rest of the clinical isolates clustering in one group. The reference strains CIP542 and A77 formed a third group (Table 1). When classified according to adhesion at $33^{\circ} \mathrm{C}$ and $37^{\circ} \mathrm{C}$, strain CIP542 grouped with the clinical isolates, whereas strain A77 was unique (Tables 2 and 3).

\section{Cytotoxicity assay}

The nine $H$. ducreyi sonicates were tested for their ability to cause death of the epithelial cells at the two
Table 1. Duncan grouping illustrating grouping of $H$. ducreyi strains in terms of their ability to attach to epithelial cells

\begin{tabular}{lcc}
\hline Strain no. & $\begin{array}{c}\text { Difference in mean* } \\
\log _{10} \text { cfu/monolayer }\end{array}$ & $\begin{array}{c}\text { Duncan } \\
\text { grouping }\end{array}$ \\
\hline SA68 & 2.9300 & A \\
SA42 & 2.5110 & A B \\
SA60 & 2.2570 & A B \\
SA71 & 2.0090 & B C \\
SA63 & 1.4960 & C D \\
SA26 & 0.9830 & D \\
SA77 & 0.9660 & D \\
CIP542 & 0.0050 & E \\
A77 & -0.0080 & E \\
\hline
\end{tabular}

${ }^{*}$ Indicates the differences in means at $33^{\circ} \mathrm{C}$ and $37^{\circ} \mathrm{C}$. Means with the same letter are not significantly different.

temperatures $\left(33^{\circ} \mathrm{C}\right.$ and $\left.37^{\circ} \mathrm{C}\right)$. In all strains, cell death was the same at both temperatures (Fig. 4). The ability to cause cell death varied from isolate to isolate, with strains SA26 and SA71 causing the lowest cell death of c. $40 \%$. The highest cell death of $c .80 \%$ was shown by strains SA42 and SA77. Although toxicity was the same at both temperatures for all clinical isolates, strain SA77 had significantly lower toxicity than strain CIP542 and the clinical isolates. Toxicity with live bacteria was greater at $33^{\circ} \mathrm{C}$ than at $37^{\circ} \mathrm{C}$ (Table 4 ).
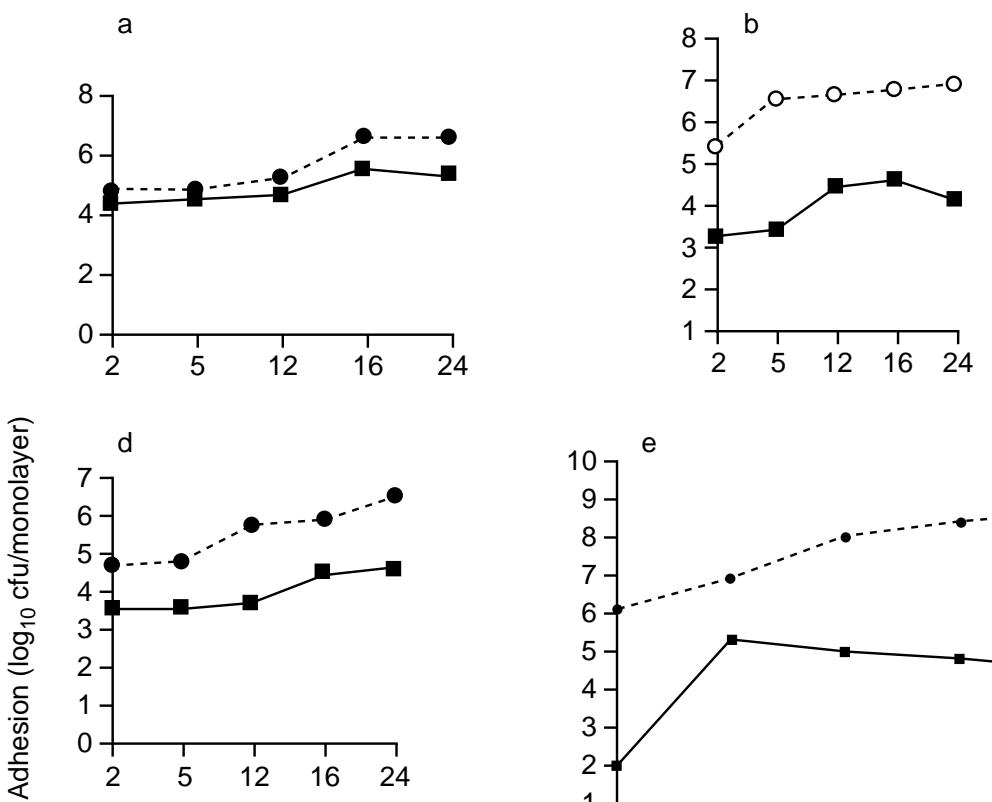

g

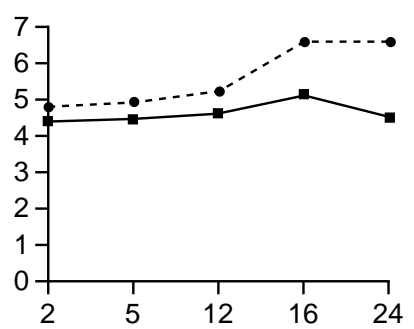

C
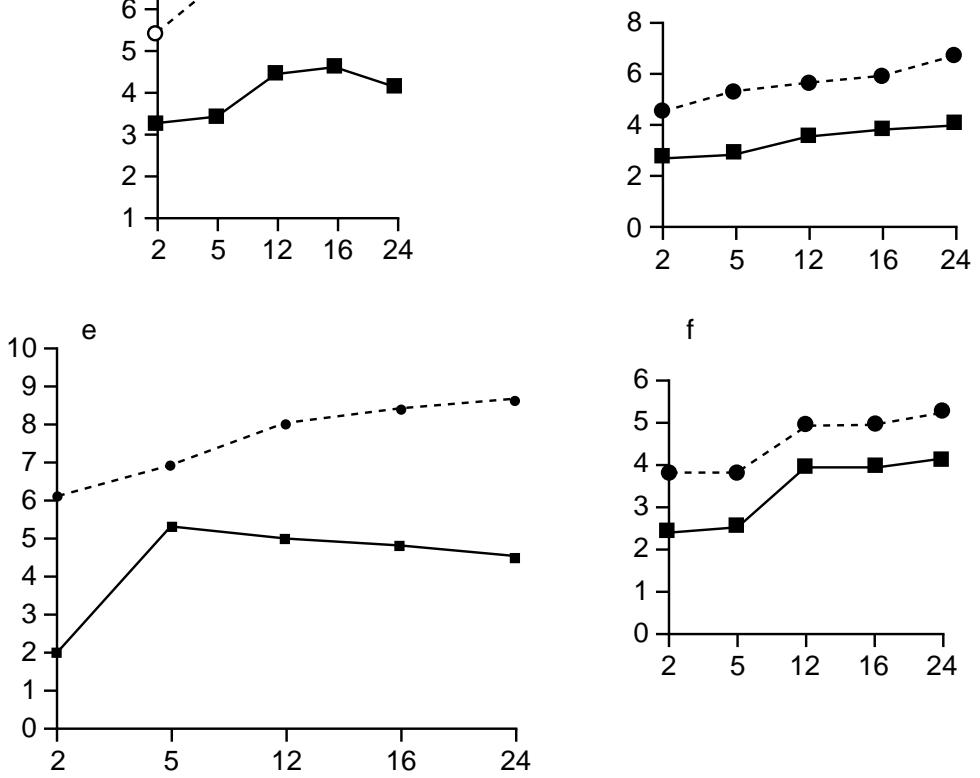

Incubation time (h)

Fig. 3. Adhesion kinetics of individual clinical isolates at $33^{\circ} \mathrm{C}(---)$ and $37^{\circ} \mathrm{C}(-)$. 
Table 2. Duncan grouping illustrating grouping of $H$. ducreyi strains in terms of their ability to attach to epithelial cells at $33^{\circ} \mathrm{C}$

\begin{tabular}{lcc}
\hline Strain no. & $\begin{array}{c}\text { Difference in mean* } \\
\log _{10} \text { cfu/monolayer }\end{array}$ & $\begin{array}{c}\text { Duncan } \\
\text { grouping }\end{array}$ \\
\hline SA68 & 7.567 & $\mathrm{~A}$ \\
SA26 & 5.607 & $\mathrm{~B}$ \\
SA60 & 5.562 & $\mathrm{~B}$ \\
SA63 & 5.467 & $\mathrm{~B}$ \\
SA42 & 5.443 & $\mathrm{~B}$ \\
SA71 & 5.325 & $\mathrm{~B}$ \\
SA77 & 4.995 & $\mathrm{~B}$ C \\
CIP542 & 4.575 & $\mathrm{C}$ \\
A77 & 1.646 & $\mathrm{D}$ \\
\hline
\end{tabular}

*Indicates the differences in means at $33^{\circ} \mathrm{C}$ and $37^{\circ} \mathrm{C}$. Means with the same letter are not significantly different.

Table 3. Duncan grouping illustrating grouping of $H$. ducreyi strains in terms of their ability to attach to epithelial cells at $37^{\circ} \mathrm{C}$

\begin{tabular}{lcc}
\hline Strain & $\begin{array}{c}\text { Difference in mean* } \\
\log _{10} \text { cfu/monolayer }\end{array}$ & $\begin{array}{c}\text { Duncan } \\
\text { grouping }\end{array}$ \\
\hline SA68 & 4.637 & $\mathrm{~A}$ \\
SA26 & 4.624 & $\mathrm{~A}$ \\
SA60 & 3.305 & $\mathrm{C}$ \\
SA63 & 3.971 & $\mathrm{~B}$ \\
SA42 & 2.932 & $\mathrm{C}$ \\
SA71 & 3.316 & $\mathrm{C}$ \\
SA77 & 4.029 & $\mathrm{~B}$ \\
CIP542 & 5.570 & $\mathrm{~A}$ \\
A77 & 1.650 & $\mathrm{D}$ \\
\hline
\end{tabular}

*Indicates the differences in means at $33^{\circ} \mathrm{C}$ and $37^{\circ} \mathrm{C}$. Means with the same letters are not significantly different.

\section{Microscopy}

Fig. 5 shows electron micrographs of HaCaT cells infected with $H$. ducreyi. Large numbers of bacteria were seen to be associated with epithelial cells. A
Table 4. Cytotoxicity of live bacteria for epithelial cells at $33^{\circ} \mathrm{C}$ and $37^{\circ} \mathrm{C}$

\begin{tabular}{lcc}
\hline & \multicolumn{2}{c}{ Cell death $(\%)$ at } \\
\cline { 2 - 3 } Strain no. & $33^{\circ} \mathrm{C}$ & $37^{\circ} \mathrm{C}$ \\
\hline Control & 0 & 0 \\
CIP542 & 29 & 30 \\
A77 & 8 & 8 \\
SA42 & 40 & 28 \\
SA60 & 42 & 34 \\
SA68 & 71 & 37 \\
\hline
\end{tabular}

prominent feature at both temperatures was an electrondense area with no recognisable membrane where the bacteria were associated with the epithelial cells (Fig. 5a). Some bacteria were located within the epithelial cells; those were enclosed within vesicles. Epithelial cell necrosis was more apparent at $33^{\circ} \mathrm{C}$ (Fig. 5b) than at $37^{\circ} \mathrm{C}$ (Fig. $5 \mathrm{c}$ ). The membrane-bound necrotic area may represent a phagolysosome. There were changes in nucleus morphology with nuclei being pushed towards the cell periphery at $33^{\circ} \mathrm{C}$, whereas at $37^{\circ} \mathrm{C}$ nuclei had only slightly changed morphology.

\section{Discussion}

This study examined the interaction of $H$. ducreyi with cultured human epithelial cells and compared this interaction at $33^{\circ} \mathrm{C}$ and $37^{\circ} \mathrm{C}$. Numerous studies have reported on in-vitro systems to investigate the interaction of $H$. ducreyi with epithelial cells $[6,8,10,17]$. However, these reports used the standard approach in virulence studies for human pathogens, i.e., incubation temperatures of $35-37^{\circ} \mathrm{C}$. Because the optimal growth temperature for $H$. ducreyi is $33^{\circ} \mathrm{C}[9,13,14]$, as

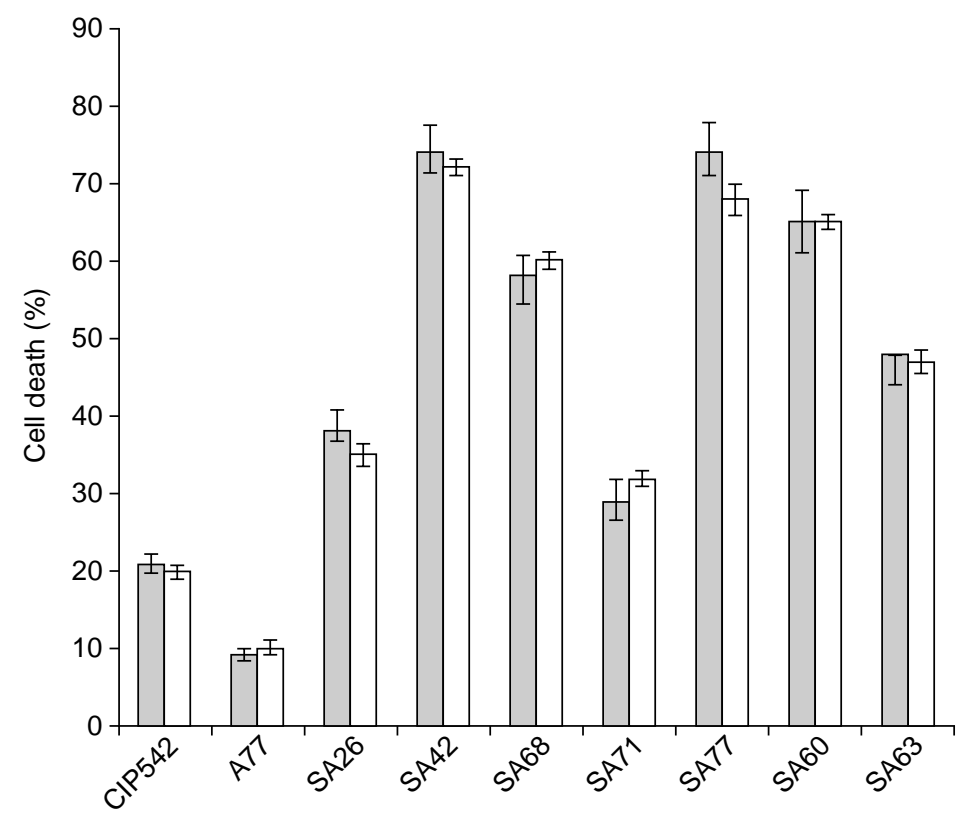

Fig. 4. Cytotoxicity assay results with crude sonicates showing the same toxicity at $33^{\circ} \mathrm{C}(\square)$ and $37^{\circ} \mathrm{C}(\square) ; \mathrm{p}>0.95$. 


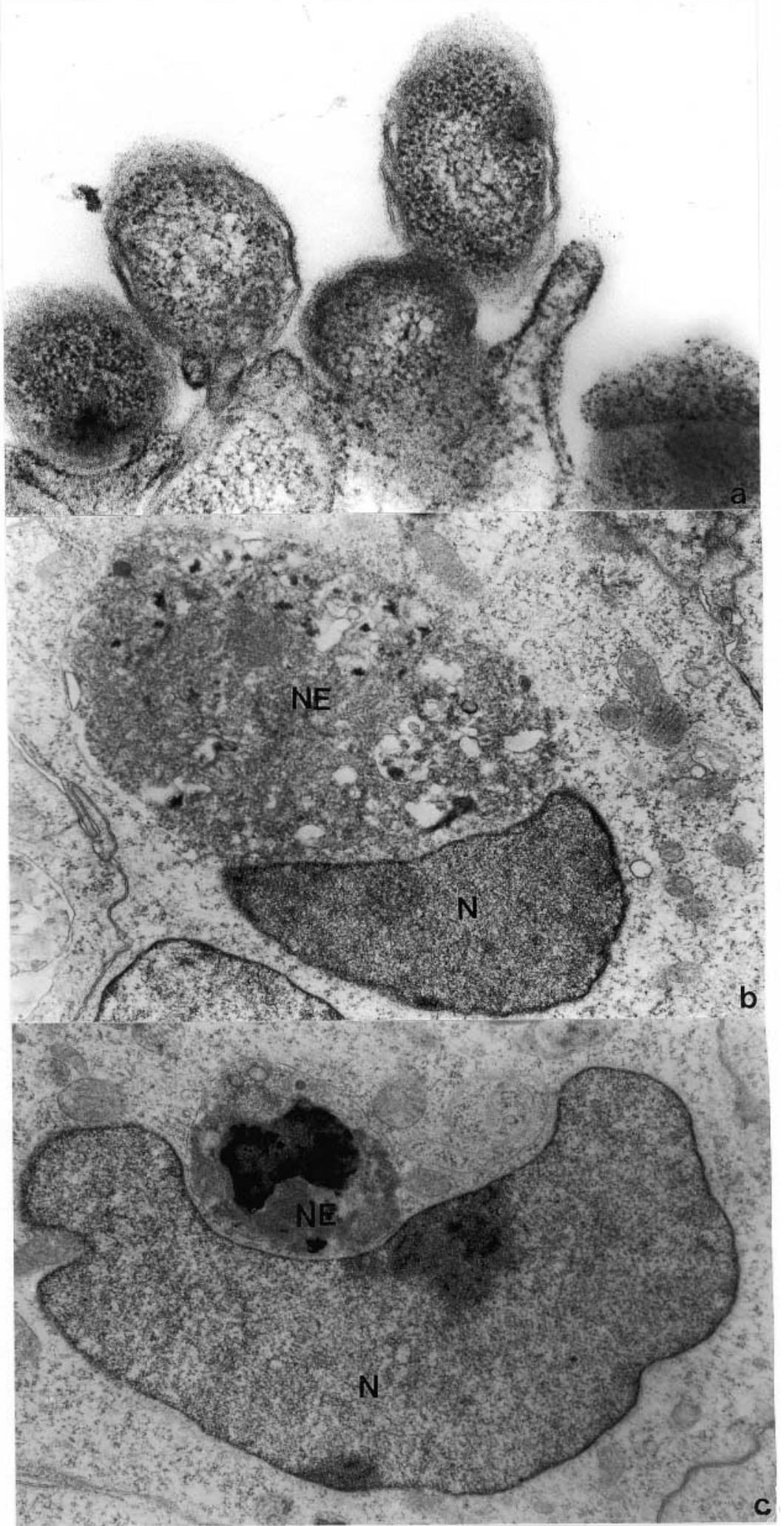

Fig. 5. Numerous bacteria associated with a HaCaT cell (a) as revealed by electron microscopy. Necrosis (NE) is more apparent at $33^{\circ} \mathrm{C}(\mathbf{b})$ as compared with $37^{\circ} \mathrm{C}(\mathbf{c})$. Note the nucleus $(\mathrm{N})$ which is pushed to the cell periphery at $33^{\circ} \mathrm{C}$. Magnifications: $a, \times 108000 ; \mathrm{b}, \times 18400 ; \mathrm{c}, \times 12000$.

related to its preference for colder parts of the body, it makes sense to investigate virulence attributes at that temperature as well. The primary organ infected by $H$. ducreyi in vivo is the skin, which has a physiological temperature of $c .33^{\circ} \mathrm{C}$. The present study demonstrated that clinical isolates of $H$. ducreyi had greater adhesion kinetics at $33^{\circ} \mathrm{C}$ than at $37^{\circ} \mathrm{C}(\mathrm{p}=0.0016)$.

The adhesion kinetics of reference strain A77 were low, and were similar at $33^{\circ} \mathrm{C}$ and $37^{\circ} \mathrm{C}$. The finding of low 
adhesion kinetics of this strain at $37^{\circ} \mathrm{C}$ is in keeping with those reported by other investigators [7, 18]. Hollyer and Alfa [7] reported low numbers of bacteria associated with epithelial cells, as well as low cytopathic effect. This may be attributed to the fact that this is an avirulent strain, and may be a result of multiple deficiencies in virulence properties. More work needs to be done to determine the difference between this strain and virulent strains. With this strain, the number of bacteria associated with the epithelial cells dropped after incubation for $16 \mathrm{~h}$ at both temperatures. This was also found with the clinical isolates, but only at $37^{\circ} \mathrm{C}$. There are several explanations for this phenomenon. Bacteria could be dying due to environmental changes; in a tissue-culture system such changes result from cell metabolism. No differences in epithelial cell density were observed at the two temperatures studied and the bacterial replication rate was higher at $33^{\circ} \mathrm{C}$; therefore, this explanation is unlikely. The phenomenon could also be due to bacteria being effectively internalised. This possibility was ruled out, as electron microscopy revealed no internal bacteria and also the amikacin protection/ invasion assay showed no difference in invasion at either temperature with clinical isolates, while negligible invasion occurred with strain A77. Another explanation is that strain A77 loses the capacity to adhere to the cells over time at both temperatures while the clinical isolates do so at $37^{\circ} \mathrm{C}$ only. This supports the hypothesis that better adhesion at $33^{\circ} \mathrm{C}$ is related to virulence.

Reference strain CIP542 also showed similar adhesion kinetics to strain A77 at the two temperatures tested. Although higher numbers of bacteria were associated with the epithelial cells as compared with strain A77, the strains grouped together in Duncan's multiple range test. However, because CIP542 is a virulent strain, it is expected to display similar adhesion kinetics to the clinical isolates. With respect to adherence over time, strain CIP542 resembled clinical isolates. There was no decrease up to $24 \mathrm{~h}$ at both temperatures tested. An explanation for the difference in temperature attachment behaviour of these strains as compared with the clinical isolates could be that the two reference strains are relatively old strains with high passage numbers compared with the clinical isolates used; therefore, they have adapted to in-vitro conditions, i.e., growth at 35$37^{\circ} \mathrm{C}$. Inter-strain variation was noted for adherence at both temperatures. This may be attributed to different levels of adhesin expression, thus allowing diversity in attachment [19]. Cytotoxicity studies showed a difference in the interaction of the free toxin at molecular as compared with the biological level. Whereas toxin preparations had a similar effect at both temperatures, with strain A77 having lower toxicity than strain CIP542 and the clinical isolates, the toxic effect of metabolically active bacteria was higher at $33^{\circ} \mathrm{C}$. The clinical isolates also displayed a diverse toxic effect on the epithelial cells at a molecular level.
This report describes, for the first time, the interaction of $H$. ducreyi with human epithelial cells at $33^{\circ} \mathrm{C}$. It has demonstrated that $H$. ducreyi clinical isolates display a temperature-dependent interaction with human epithelial cells. Furthermore, the overall toxic effect of whole bacteria depends on the metabolic activity of the bacteria and, therefore, was greater at $33^{\circ} \mathrm{C}$ than at $37^{\circ} \mathrm{C}$. However, the effect of the free toxin at molecular level with fixed toxin concentrations is a temperature-independent event. These findings suggest that expression of adhesion to keratinocytes is upregulated at the lower temperature and that this is directly related to virulence.

\section{References}

1. Abeck D, Johnson AP. Pathophysiological concept of Haemophilus ducreyi infection (chancroid). Int J STD AIDS 1992; 3: 319-323.

2. Cameron DW, Simonsen JN, D'Costa LJ et al. Female to male transmission of human immunodeficiency virus type 1: risk factors for seroconversion in men. Lancet 1989; 2: 403-407.

3. Morse SA. Chancroid and Haemophilus ducreyi. Clin Microbiol Rev 1989; 2: 137-157.

4. Plummer FA, Simonsen JN, Cameron DW et al. Cofactors in male-female sexual transmission of human immunodeficiency type 1. J Infect Dis 1991; 163: 233-239.

5. Beachey EH. Bacterial adherence: adhesin-receptor interactions mediating the attachment of bacteria to mucosal surfaces. $J$ Infect Dis 1981; 143: 325-345.

6. Abeck D, Korting HC. Mechanisms of skin adherence, penetration and tissue necrosis production by Haemophilus ducreyi, the causative agent of chancroid. Acta Dermatol Venereol Suppl 1991; 174: 1-20.

7. Hollyer TT, De Gagne PA, Alfa MJ. Characterization of the cytopathic effect of Haemophilus ducreyi. Sex Transm Dis 1994; 21: 247-257.

8. Lammel CJ, Dekker NP, Palefsky J, Brooks GF. In vitro model of Haemophilus ducreyi adherence to and entry into eukaryotic cells of genital origin. J Infect Dis 1993; 167: 642-650.

9. Schmid GP, Faur YC, Valu JA, Sikandar SA, McLaughlin MM. Enhanced recovery of Haemophilus ducreyi from clinical specimens by incubation at 33 versus $35^{\circ} \mathrm{C}$. J Clin Microbiol 1995; 33: $3257-3259$

10. Alfa MJ, Stevens MK, DeGagne P, Klesney-Tait J, Radolf JD, Hansen EJ. Use of tissue culture and animal models to identify virulence-associated traits of Haemophilus ducreyi. Infect Immun 1995; 63: 1754-1761.

11. Brentjens RJ, Spinola SM, Campagnari AA. Haemophilus ducreyi adheres to human keratinocytes. Microb Pathog 1994; 16: $243-247$.

12. Finlay BB, Falkow S. Common themes in microbial pathogenicity. Microbiol Rev 1989; 53: 210-230.

13. Sturm AW. Identification of Haemophilus ducreyi. Antonie Van Leeuwenhoek 1981; 47: 89-90.

14. Sturm AW, Zanen HC. Characteristics of Haemophilus ducreyi in culture. J Clin Microbiol 1984; 19: 672-674.

15. Lagergård T, Purvén M, Frisk A. Evidence of Haemophilus ducreyi adherence to and cytotoxin destruction of human epithelial cells. Microb Pathog 1993; 14: 417-431.

16. Saville DJ. Multiple comparison procedures: the practical solution. Am Stat 1990; 44: 174-180.

17. Shar L, Davies HA, Wall RA. Association of Haemophilus ducreyi with cell-culture lines. J Med Microbiol 1992; 37: 268-272.

18. Odumeru JA, Wiseman GM, Ronald AR Virulence factors of Haemophilus ducreyi. Infect Immun 1984; 43: 607-611.

19. Hultgren SJ, Abraham S, Caparon M, Falk P, St Geme JW, Normark S. Pilus and nonpilus bacterial adhesins: assembly and function in cell recognition. Cell 1993; 73: 887-901. 